Volume 8. No. 10, October 2020

International Journal of Emerging Trends in Engineering Research

Available Online at http://www.warse.org/IJETER/static/pdf/file/ijeter1098102020.pdf

https://doi.org/10.30534/ijeter/2020/1098102020

\title{
Improvement of the structural scheme of technical and technological complex management
}

\author{
Vladimir Gruzin $^{1}$, Aigul Tulembayeva ${ }^{2}$, Aidar Berdibekov $^{3}$ \\ ${ }^{1}$ National University of Defense of the First President of the Republic of Kazakhstan - Elbasy, Nur-Sultan, \\ Kazakhstan, vladimir.gruzin@inbox.ru \\ ${ }^{2}$ National University of Defense of the First President of the Republic of Kazakhstan - Elbasy, Nur-Sultan, \\ Kazakhstan, aigul.tulembayeva@mail.ru \\ ${ }^{3}$ National University of Defense of the First President of the Republic of Kazakhstan - Elbasy, Nur-Sultan, \\ Kazakhstan, aidar.berdibekov@mail.ru
}

\begin{abstract}
In the article the features of influence of factors of external and internal environment of the technical-technological complex industry (TCO) that affect efficiency of its operation and under the provisions of a systematic approach in the form of complex organizational-technical systems. Taking into account the analysis of the proposed features and their options for selecting possible indicators in the process of creating a TTCO, a matrix of preferences in choosing the main requirements for the future complex organizational and technical system of the TTC was formed and its structural scheme was developed.

Based on the provisions of the system approach and studies of the organizational and technical state of the TTC, methodological requirements for the formulation and structuring of the goals of the entire industry have been fulfilled. The main scientific provisions that define the essence of TTCO functioning are its General purpose and sub-goals of the main hierarchical levels of the structural scheme of the industry management system.

The levels of hierarchy are defined and, taking into account the functions of technological support, the management structure in the TTCO system is proposed, which includes five levels of hierarchy.
\end{abstract}

Key words : synergetic system, technical and technological complex, industry, management, feature, block diagram, factors of external and internal environment, information flow, hierarchical structure.

\section{INTRODUCTION}

With the continuous development of industries and areas of human activity, improving the management of complex organizational and economic systems, the development of science and technology, and the complexity of production and technological processes at enterprises, the problem of timely adoption of rational decisions from a variety of alternative options has significantly emerged. At present, new classes of objects and relations between them are increasingly being identified, which are either impossible or too difficult to investigate using the methods of traditional scientific disciplines. And although on the way of integration, special Sciences retain their independence and quality specificity, they do not reduce one to another, nevertheless, their actual data and theoretical constructions are United around system methods of research, as a General method that integrates scientific knowledge in order to increase its practical effectiveness.

Systematic research is the most effective manifestation of this trend, since it is interdisciplinary in nature, and helps to solve various complex problems that are located at the intersection of various scientific and natural disciplines. There is a generally accepted view that the traditional division of science into classical disciplines currently does not fully meet the needs of scientific knowledge. On the other hand, for the study and research of complex objects in order to obtain rational characteristics and parameters in management, Economics, politics, sociology, technology, psychology, and so on, it is impossible to provide an adequate description of them within a single scientific discipline. Therefore, finding General principles of research and specific scientific research methods, which are not traditional due to the non-traditional object of research, requires a special approach $[1,2,3,4]$.

Numerous studies of scientists have found that the sign of insufficient consistency in the activities of the existing system is the manifestation of a problem or problems. At the same time, the solution of the problem that has arisen can only be implemented by moving it to a new and higher level of systemicity [5].

\section{ANALYSIS OF FACTORS AFFECTING THE FUNCTIONING OF A COMPLEX ORGANIZATIONAL AND TECHNICAL SYSTEM}

The main concept in the general theory of complex systems is the concept of "system", which indicates and assumes that the set of properties of the elements that make up the system, 
which are in relations or connections with each other, form an integrity or organic unity. Based on the above, the "complex system" consists of two components: a set of subsystems and elements and a set of direct and inverse relationships between these subsystems and elements, and its research in the search for the most acceptable solutions to specific practical problems, taking into account the influence of the external environment, should be carried out on the basis of a system methodology [6].

With the increasing complexity of the management sector in difficult economic conditions, stable enough political situation in various regions of the earth, by contraction in others-industries the industrial sector of the state economy, complication of technological processes and so on, has significantly increased the relevance of timely resolution of problems, increased costs of imple-tion, complicated methods of rational decision-making when you-bora options for the creation and directions of development of organizational-technical systems and facilities for technical and technological complexes, as well as managing them.

A significant number of factors of organizational, economic, technological, and political nature constantly influence the processes of ensuring the stability of society's development, determining the need to use a special approach to solving emerging problems. The desire of scientific knowledge for universal integration and system representations of the surrounding reality make it necessary to apply the methodology of a systematic approach to solving emerging problems, which allows:

- In each case, create a general context for the next tasks or problems;

- Bring all the initially scattered and redundant information about the problem situation into a single integrated system;

- Derive one view from another that is related to a single activity, and coordinate the goals of different levels in the hierarchy of management of a complex system.

- The methodological nature of the system approach is as follows:

- In the system approach, the main emphasis is not on one-sided analytical and linear-causal research methods, but on the analysis of integral relationships and structures that contribute to the creation of new theoretical concepts and a new type of knowledge when creating and studying systems of different types and classes;

- The system approach is a research principle that looks at the system as a whole, rather than its individual subsystems, and its task is to optimize the system as a whole, rather than improve the efficiency of its subsystems;

- The system approach is the most universal and integrative in nature, and therefore it is based on a single evolutionary approach that considers the development of all types and types of complex systems as a single and regular process, from elementary particles to the social organization of society.

The ratio "external environment - system" is the main one in the process of conducting a system approach, in which the complex system itself is considered as an integrated whole, and not by its individual component elements and subsystems. Therefore, its main task is to optimize and improve the object or process presented as a system as a whole, and not to improve the efficiency of functioning of its subsystems.

The main objectives of the system approach are to develop methods for analyzing and synthesizing objects, describing their integral characteristics, in particular, as a result of presenting the studied and constructed objects as purposeful systems, synthesizing "elemental" and" integral " knowledge about the studied objects, analyzing the relationship of the studied systems with other systems that make up their environment.

Analyzing all of the above and summarizing the main conclusions of scientists, it should be determined that the system approach can be considered as a methodology for creating, research and design, as a general conceptual framework, a new scientific method, a method for analyzing organizations, system management, a method related to system design, operations research, economic evaluation, and so on.

Since the relation "external environment-system" is fundamental for determining the place and functions of the system approach in scientific knowledge, this relation fixes the difference and relationship between different ways of representing objects (mechanistic and integral) and different methods of their research (elementalist, reductionist, on the one hand, and synthetic-on the other).

\section{IMPROVING THE STRUCTURE OF THE TECHNICAL AND TECHNOLOGICAL COMPLEX OF THE INDUSTRY, TAKING INTO ACCOUNT ITS EXTERNAL AND INTERNAL FACTORS}

To present the ttc as a well-balanced synergistic system, it is necessary to:

In accordance with the retrospective analysis of the origin, development and formation of the industry;

Based on the review and analysis of existing regulatory and legal acts on the activities of structural divisions of the industry;

Based on the review and analysis of the experience of forming industry management structures in the near and far abroad countries

Formulate the main features of the future complex organizational and technical system [8].

The main features that should be taken into account in the process of developing the structural scheme of the ttc, taking into account the factors of the external and internal environment, include the following:

- Hierarchical structure of the TTC:

$\checkmark$ Option 1-can be defined (set) by the governing body;

$\checkmark$ Option 2-generated by the industry's own safety assurance system (SOBO);

- internal structure of TTC subsystems and elements:

$\checkmark$ Option 1-not essential for performing its functions;

$\checkmark$ Option 2-has a certain value for effective functioning; 
- management:

$\checkmark$ Option 1-the created TTC system and its subsystems are managed by the governing body and may not be equally strict at different levels of its hierarchy;

$\checkmark$ Option 2 is a relatively Autonomous system of governance the TTC is ordered to a dynamic network of their own;

- the concept of order:

$\checkmark$ Option 1 - the structure of the TTC, determined by laws and regulations;

$\checkmark$ Option 2-emergent self-creation from fluctuations in the course of TTC self-organization;

- parameters of the TTC system:

$\checkmark$ Option 1-set externally by the governing body;

$\checkmark$ Option 2-generated by ITSELF and the TTC system itself (CA-monostroika);

- causal relationships within the TTC system:

$\checkmark$ Option 1 - linear cause-and-effect relationship;

$\checkmark$ Option 2-cyclic relationships - the output signal can be an input for the same subsystem or element of the TTC system;

- the principle of selection of enterprises in the process of forming the TTC:

$\checkmark$ Option 1-by function;

$\checkmark$ Option 2-by belonging of the existing subsystem and its elements to the SOBO and to the TTC system itself;

\section{- thermodynamic state of the TTC:}

$\checkmark$ Option 1-equilibrium (static equilibrium), since the system is relatively closed;

$\checkmark$ Option 2-not equilibrium (dynamic equilibrium), since the system is open;

- influence of the external environment (Vnsr) on the TTC:

$\checkmark$ Option 1-negatively affects the unchangeable TTC system;

$\checkmark$ Option 2-influences and structures the TTC system;

- behavior of the TTC system in relation to the Vnsr:

$\checkmark$ Option 1-when the medium is disturbed, it tends to return to the equilibrium state;

$\checkmark$ Option 2-provides an active counteraction, and within certain limits can "manipulate" the Gnsr;

- boundary conditions for the behavior of the TTC system: $\checkmark$ Option 1-determined by a pre-developed program for it by the governing body;

$\checkmark$ Option 2-determine the TTC system itself from the conditions and requirements of the SOBO (self-preservation conditions);

- nature and features of the development of the TTC:

$\checkmark$ Option 1-trajectory set by the governing body (reversibility);

$\checkmark$ Option 2-adaptive development process (irreversibility);

- life cycle time of the system, subsystems, and elements of the TTC:

$\checkmark$ Option 1-absolute, uniform, uniform;

$\checkmark$ Option 2-system, relative.

Based on the analysis of the proposed features and their options for selecting possible indicators in the process of creating a structural scheme of the TTC, we will form a matrix of the main requirements for the future system (see table 1).

Table 1: Matrix of preferences in choosing the main requirements for the future structure of the technical and technological complex system

\begin{tabular}{|c|c|c|c|c|}
\hline № & $\begin{array}{l}\text { The name of a } \\
\text { characteristic } \\
\text { TTC }\end{array}$ & $\begin{array}{l}\text { Op } \\
\text { tion } \\
1\end{array}$ & $\begin{array}{l}\text { Op } \\
\text { tio } \\
\text { n } \\
2\end{array}$ & Note \\
\hline 1 & 2 & 3 & 4 & 5 \\
\hline 1 & $\begin{array}{l}\text { Hierarchical structure: } \\
\text { - can be defined (set) by } \\
\text { the governing body; } \\
\text { - generated by SOBO. }\end{array}$ & + & + & $\begin{array}{l}\text { Depending } \\
\text { on the } \\
\text { industry's } \\
\text { objectives } \\
\text { and } \\
\text { requirement } \\
\text { s SOBO }\end{array}$ \\
\hline 2 & $\begin{array}{l}\text { Internal structure of } \\
\text { subsystems and elements: } \\
\text { - not essential for the } \\
\text { performance of its } \\
\text { functions; } \\
\text { - has a certain value for } \\
\text { effective functioning. }\end{array}$ & + & + & \\
\hline 3 & $\begin{array}{l}\text { Management: } \\
\text { - the created system and } \\
\text { its subsystems are } \\
\text { managed by the governing } \\
\text { body; } \\
\text { - relatively Autonomous } \\
\text { control system. }\end{array}$ & + & + & $\begin{array}{l}\text { Depending } \\
\text { on the } \\
\text { industry's } \\
\text { objectives } \\
\text { and } \\
\text { requirement } \\
\text { s SOBO } \\
\end{array}$ \\
\hline 4 & $\begin{array}{l}\text { The concept of order: } \\
\text { - the structure is } \\
\text { determined by laws and } \\
\text { regulations; } \\
\text { - emergent self-creation } \\
\text { in the course of } \\
\text { self-organization. }\end{array}$ & + & + & \\
\hline 5 & $\begin{array}{l}\text { System parameters: } \\
\text { - set externally by the } \\
\text { governing body; } \\
\text { - are generated by } \\
\text { themselves and the system } \\
\text { SOBO }\end{array}$ & + & + & $\begin{array}{l}\text { Depending } \\
\text { on the } \\
\text { industry's } \\
\text { objectives } \\
\text { and } \\
\text { requirement } \\
\text { s SOBO } \\
\end{array}$ \\
\hline 6 & $\begin{array}{l}\text { Cause-and-effect } \\
\text { relationships within the } \\
\text { system: } \\
\text { - linear causal } \\
\text { relationships; } \\
\text { - cyclical relationships }\end{array}$ & + & + & $\begin{array}{l}\text { Due to the } \\
\text { tasks of the } \\
\text { TTC system }\end{array}$ \\
\hline 7 & $\begin{array}{l}\text { Principle of selection of } \\
\text { enterprises } \\
\text { - on a functional basis; } \\
\text { - according to the }\end{array}$ & + & + & $\begin{array}{l}\text { Taking into } \\
\text { account the } \\
\text { existing } \\
\text { TTC system }\end{array}$ \\
\hline
\end{tabular}




\begin{tabular}{|c|c|c|c|c|}
\hline & $\begin{array}{l}\text { belonging of the existing } \\
\text { subsystem and its } \\
\text { elements to SOBO and to } \\
\text { the system itself. }\end{array}$ & & & $\begin{array}{l}\text { and } \\
\text { industrial } \\
\text { development }\end{array}$ \\
\hline 8 & $\begin{array}{l}\text { Thermodynamic state: } \\
\text { - equilibrium; } \\
\text { - not in equilibrium. }\end{array}$ & + & + & \\
\hline 9 & $\begin{array}{l}\text { Impact Of The Gnsr: } \\
\text { - negatively affects the } \\
\text { immutable system; } \\
\text { - influences and } \\
\text { structures the system. }\end{array}$ & + & + & \\
\hline 10 & $\begin{array}{l}\text { Behavior of the system in } \\
\text { relation to the Vnsr: } \\
\text { - when the medium is } \\
\text { disturbed, it tends to } \\
\text { return to the equilibrium } \\
\text { state; } \\
\text { - provides active } \\
\text { resistance, and within } \\
\text { certain limits can } \\
\text { "manipulate" the Vnsr. }\end{array}$ & + & + & \\
\hline 11 & $\begin{array}{l}\text { Boundary conditions for } \\
\text { the system behavior: } \\
\text { - determined by the } \\
\text { program developed for it } \\
\text { by the governing body; } \\
\text { - are determined by the } \\
\text { system itself from the } \\
\text { conditions } \\
\text { requirements of the } \\
\text { system SOBO. }\end{array}$ & + & + & \\
\hline 12 & $\begin{array}{l}\text { Character and features of } \\
\text { development: } \\
\text { - trajectory set by the } \\
\text { governing body; } \\
\text { - adaptive development } \\
\text { process. }\end{array}$ & + & + & $\begin{array}{l}\text { Taking into } \\
\text { account the } \\
\text { requirement } \\
\mathrm{s} \text { of the } \\
\text { SOBO and } \\
\text { the features } \\
\text { of the } \mathrm{Vnsr}\end{array}$ \\
\hline 13 & $\begin{array}{l}\text { Life cycle time of the } \\
\text { system, subsystems, and } \\
\text { elements: } \\
\text { - absolute, uniform, } \\
\text { uniform; } \\
\text { - system, relative. }\end{array}$ & + & + & \\
\hline
\end{tabular}

For a more visualized presentation of the procedure of a systematic approach in learning the peculiarities of the creation of TCO developed the following block diagram (see figure 1) implementation, which includes consideration of the system given its structure, relationships with the external environment, the establishment of basic principles of management and analyze the process of its functioning.

3) Improvement of the structural scheme for managing the technical and technological complex of the industry

In accordance with the structural scheme of the study of the TTC system, developed on the basis of the provisions of the system approach (see table 1, figure 1) and the study of its organizational and technical state, methodological requirements for the formulation and structuring of the goals of the industry are set. The main scientific provisions that determine the essence of TTCO functioning are its General purpose and sub-goals of the main hierarchical levels of its structural scheme (see table 2), determining the integrative qualities and dividing the control system into the required set of its component subsystems.

1) Formulation of the goals of the TTCO system functioning. The General purpose of TTCO functioning is to ensure the appropriate functions of its activities, taking into account the reliability and integrity of its structural components on the basis of technological, military, economic, social, legal, informational, political and other spheres of activity in the state.

Table 2: Sub-goals of the main hierarchical levels of the structural scheme of the technical and technological complex management system

\begin{tabular}{|c|c|c|}
\hline \multirow[t]{4}{*}{1} & \multicolumn{2}{|c|}{ Sub-goals of the first hierarchical level: } \\
\hline & 1.1 & $\begin{array}{l}\text { preparation for the functioning of the entire } \\
\text { industry and its structural divisions as a whole; }\end{array}$ \\
\hline & 1.2 & $\begin{array}{l}\text { ensuring the effective functioning of the TTC } \\
\text { structural divisions as a technological } \\
\text { multi-profile sector of the state's economy that } \\
\text { can meet the needs of the industry itself and } \\
\text { other related industries in the state, as well as } \\
\text { ensure the strategic presence of the state's } \\
\text { industry in the world markets of technological } \\
\text { products and services; }\end{array}$ \\
\hline & 1.3 & $\begin{array}{l}\text { ensuring technological independence in the } \\
\text { production of strategic and other samples of } \\
\text { technical systems in accordance with the state } \\
\text { program for the development of the industry. }\end{array}$ \\
\hline \multirow[t]{5}{*}{2} & \multicolumn{2}{|c|}{ Sub-goals of the second hierarchical level: } \\
\hline & 2.1 & $\begin{array}{l}\text { increasing the intellectual potential and } \\
\text { qualitative improvement of the TTC personnel, } \\
\text { ensuring social protection of its employees; }\end{array}$ \\
\hline & 2.2 & $\begin{array}{l}\text { formation of a base of priority technologies and } \\
\text { activation of innovative and investment } \\
\text { activities that ensure the creation of a leading } \\
\text { scientific and technological reserve in order to } \\
\text { develop fundamentally new models of technical } \\
\text { systems that have previously inaccessible } \\
\text { tactical and technical characteristics, ensuring a } \\
\text { stable position in the world market; }\end{array}$ \\
\hline & 2.3 & $\begin{array}{l}\text { development, improvement and production of } \\
\text { modern competitive technical systems, as well } \\
\text { as the formation of a package of services on the } \\
\text { orders of the state, timely provision of } \\
\text { re-equipment of the industry; }\end{array}$ \\
\hline & 2.4 & $\begin{array}{l}\text { implementation of high-quality updating of the } \\
\text { scientific, technical and } \\
\text { production-technological base, improvement of } \\
\text { the system of interstate cooperation and } \\
\text { guaranteed material and raw material supply, } \\
\text { creation, maintenance and implementation of }\end{array}$ \\
\hline
\end{tabular}




\begin{tabular}{|l|l|}
\hline 2.5 & $\begin{array}{l}\text { innovative technologies in the field of } \\
\text { development, production, repair and operation } \\
\text { of technical systems used in all sectors of the } \\
\text { state economy; }\end{array}$ \\
\hline $\begin{array}{l}\text { improving the system of program-target } \\
\text { planning for placing orders for the supply of } \\
\text { products, diversifying their own and borrowed } \\
\text { technologies to perform work and provide } \\
\text { services for the territorial civil sectors of the } \\
\text { state economy. }\end{array}$ \\
\hline
\end{tabular}

The relationship between the general purpose of ttco functioning and its sub-goals of the first and second hierarchical levels is shown in figure 2.

1) Determining the integrative qualities of the ttko system.

The main qualities of TTKO should be:

- The integrity and structure that can be defined (set) by the governing body and / or generated by SOBO is determined by the laws and regulations of the state;

- Optimization of the hierarchical structure of management and executive functions, taking into account the subsystems created by the governing body or its relatively autonomous management system;

- Adaptability to constantly changing influences of external and internal environments of its functioning taking into account the conditions and requirements of its $\mathrm{SOBO}$;

- Emergence, which makes it possible to increase the output of military products in the shortest possible time, or to create and launch the required types of technical systems, as well as when they are urgently needed in a special period of time for specific purposes;

- Openness and multi-functionality to ensure the necessary interaction (communication) with the civil sector of the economy.

2) Dividing the TTCO control system into the required set of its component subsystems and elements.

In accordance with the structuring of the general purpose of TTCO functioning, the main subsystems of its general structure are (see figure 3):

- TTCO management (1st level in the management hierarchy): the first head and his deputies (for technical support, scientific and production issues, economic and financial planning and strategic development, personnel policy and administration, international economic cooperation;

- Departments for strategically important areas of industry development (2nd level in the management hierarchy): analytical structural divisions, enterprises and organizations; - research (3rd level in the management hierarchy): research institutes in strategically important areas, research laboratories;

- design and engineering (3rd level in the management hierarchy): design organizations, design bureaus and experimental workshops for the production of non-standard equipment;

- industrial testing (4th level in the management hierarchy): industrial enterprises of various sectors of the economy, enterprises that are duplicates of the main types of production, testing organizations and experimental ranges.

3) Goals of functioning of each subsystem and element of the ttco system [9].

The purpose of functioning of the "ttco management" subsystem, represented as the first head and his deputies, is to determine strategically important directions in providing a set of measures and constantly improving it to meet the complex tasks of the industry.

The purpose of the subsystem "departments for strategically important areas of industry development", presented in the form of the required number of analytical centers, is to monitor the state and development of the industry in certain of its most important areas.

The purpose of functioning of the research subsystem, represented as research institutes in strategically important areas of industry development and providing products and services to related industries of the state, is to conduct technical and technological research and development of $r$ \& $\mathrm{d}$ in the relevant areas of industry science.

The purpose of functioning of the design subsystem, represented in the form of design organizations and bureaus, is to develop design and technological documentation for the production of layouts, laboratory and test full-scale samples of various types of technical systems based on preliminary research in research institutes.

The objectives of the industrial and test subsystem, represented as industrial enterprises of various sectors of the state economy, enterprises-duplicates of the main types of production, testing organizations and experimental sites, are: - production of samples of equipment tested on models or layouts and approved for experimental, small-scale and serial production, with the possibility of further diversification of the used technologies for other sectors of the state economy;

- ensuring the reliability of the main types of production located randomly in different parts of the country, and in general on the territory of the entire state;

- conducting various types of experimental research and testing of new equipment samples.

1) determination of hierarchy levels in the ttco management system.

Based on all of the above and taking into account the functions of technical and technological support for the industry, based on the vertical and horizontal decomposition of the hierarchical structure of ttco (see figure 3 ), it is proposed to form the following structure of management of the industry, including five levels of the management hierarchy (see figure 4):

I-strategic level (for providing industry leadership), which provides management of the main strategic directions in the functioning of the state's industry.

II-management level (to ensure the executive function of managing the implementation of tasks of technical and technological provision by the state industry, it is proposed to form a technical and technological committee of the industry); 


\begin{tabular}{|c|c|c|c|c|}
\hline \multirow[t]{2}{*}{ I } & \multicolumn{4}{|c|}{$\begin{array}{l}\text { Strategic level } \\
\text { (Top management of the industry) }\end{array}$} \\
\hline & $\begin{array}{l}1.1 \text { the First } \\
\text { head of the } \\
\text { sector }\end{array}$ & $\begin{array}{l}1.2 \text { Strategic } \\
\text { advice for the } \\
\text { industry }\end{array}$ & $\begin{array}{l}1.3 \text { Technical } \\
\text { and } \\
\text { technological } \\
\text { Council of the } \\
\text { industry }\end{array}$ & $\begin{array}{l}1.4 \\
\text { economic } \\
\text { Council of } \\
\text { the industry }\end{array}$ \\
\hline \multirow[t]{2}{*}{ II } & \multicolumn{4}{|c|}{$\begin{array}{l}\text { Management level } \\
\text { (Technical and technological Committee) }\end{array}$} \\
\hline & $\begin{array}{l}2.1 \quad \text { TTC } \\
\text { Guidelines }\end{array}$ & $\begin{array}{ll}2.2 & \text { TTC } \\
\text { Council } & \end{array}$ & $\begin{array}{l}2.3 \text { Heads of } \\
\text { strategic } \\
\text { divisions }\end{array}$ & $\begin{array}{l}2.4 \text { Heads of } \\
\text { analytical } \\
\text { and } \\
\text { monitoring } \\
\text { services } \\
\end{array}$ \\
\hline \multirow[t]{2}{*}{ III } & \multicolumn{4}{|c|}{$\begin{array}{l}\text { Executive level } \\
\text { (Main sectors of the industry's economy) }\end{array}$} \\
\hline & $\begin{array}{l}3.1 \text { Research } \\
\text { institutes in } \\
\text { strategic areas }\end{array}$ & $\begin{array}{l}3.2 \text { Design of } \\
\text { the organization }\end{array}$ & $\begin{array}{l}3.3 \quad \text { Main } \\
\text { industrial } \\
\text { enterprises }\end{array}$ & $\begin{array}{l}3.4 \\
\text { companies } \\
\text { that are } \\
\text { duplicates of } \\
\text { the main } \\
\text { types of } \\
\text { production the } \\
\text { in industry } \\
\text { indu }\end{array}$ \\
\hline \multirow[t]{2}{*}{ IV } & \multicolumn{4}{|c|}{$\begin{array}{l}\text { Management level } \\
\text { (Territorial Executive bodies of the industry) }\end{array}$} \\
\hline & $\begin{array}{l}4.1 \text { Territorial } \\
\text { authority of the } \\
\text { industry } \\
\text { management }\end{array}$ & $\begin{array}{l}4.2 \text { Regional } \\
\text { bodies of } \\
\text { management of } \\
\text { the industry }\end{array}$ & $\begin{array}{l}4.3 \text { Regional } \\
\text { branch } \\
\text { management } \\
\text { bodies }\end{array}$ & $\begin{array}{l}4.4 \text { Direct } \\
\text { management } \\
\text { of the } \\
\text { industry } \\
\text { enterprise }\end{array}$ \\
\hline \multirow[t]{2}{*}{$\mathrm{V}$} & \multicolumn{4}{|c|}{$\begin{array}{l}\text { Executive level } \\
\text { (Civil sector of the economy of the Republic of Kazakhstan) }\end{array}$} \\
\hline & $\begin{array}{l}5.1 \text { Enterprises } \\
\text { of strategic } \\
\text { importance for } \\
\text { the industry }\end{array}$ & $\begin{array}{l}5.2 \text { Universities } \\
\text { and research } \\
\text { institutes and } \\
\text { industry } \\
\text { enterprises }\end{array}$ & $\begin{array}{l}5.3 \text { Industrial } \\
\text { enterprises of } \\
\text { various } \\
\text { related sectors } \\
\text { of the state } \\
\text { economy }\end{array}$ & $\begin{array}{l}5.4 \\
\text { Enterprises } \\
\text { that provide } \\
\text { the supply of } \\
\text { components } \\
\text { for the } \\
\text { production } \\
\text { of main } \\
\text { products by } \\
\text { TTKO } \\
\text { plants }\end{array}$ \\
\hline
\end{tabular}

Figure 4: Improved ttco management structure

III-Executive level (it is proposed to improve the sectoral sector of the economy of the Republic of Kazakhstan in order to fulfill the state task);

IV-management level (for planning and execution of the state order, it is proposed to create territorial Executive bodies of the industry);

V-Executive level (to ensure the Executive function, all enterprises and organizations in the civil sector of the economy of the industry are required to perform their assigned tasks for the production of technical products and services for various purposes).

Management functions are performed by: top management of the state industry, management of the technical and technological Committee, and territorial Executive bodies of industry management.

Top management of the state industry is carried out under the leadership of the First head, who is the Chairman of all the following councils: strategic, technical, technological and economic.
The first head, the management of the technical and technological Committee, and the territorial Executive bodies of state industry management are vested with the following important powers:

- determine the main strategic directions of development of the industry in the state;

- approves the industry's long-term plan;

- provide the leadership for the entire industry;

- conduct negotiations and sign international treaties;

- enter into force regulatory legal acts of the industry, orders the introduction of certain measures in the industry, introduces them on the entire territory of the Republic of Kazakhstan or in its individual regions, etc.;

- exercise other powers in the field of technical and technological support of the state's industry, assigned to it by relevant decrees and other laws.

5) Build an infological system for the movement of information flows in the hierarchical structure of TTKO.

Based on the above-mentioned provisions and taking into account the developed structural schemes (see figures 1-4), the following scheme of information flows in the hierarchical structure of TTCO management when the industry fulfills a State order is proposed (see figure 5).

The proposed scheme for managing information flows in the process of fulfilling the State order by the industry will reduce the burden on the National budget and provide targeted financing for the development and modernization of production of enterprises that are part of the TTCO structure.

\section{CONCLUSION}

The necessity of applying a systematic approach to identify the main integrative indicators in the ratio "external environment - system" in order to develop a structural scheme of the TTC system is Justified.

On the basis of the main features that should be considered in the process of creating block diagrams including factors external and internal environment, developed a matrix of preferences in the choice of the main requirements to the future structure of the system TCO.

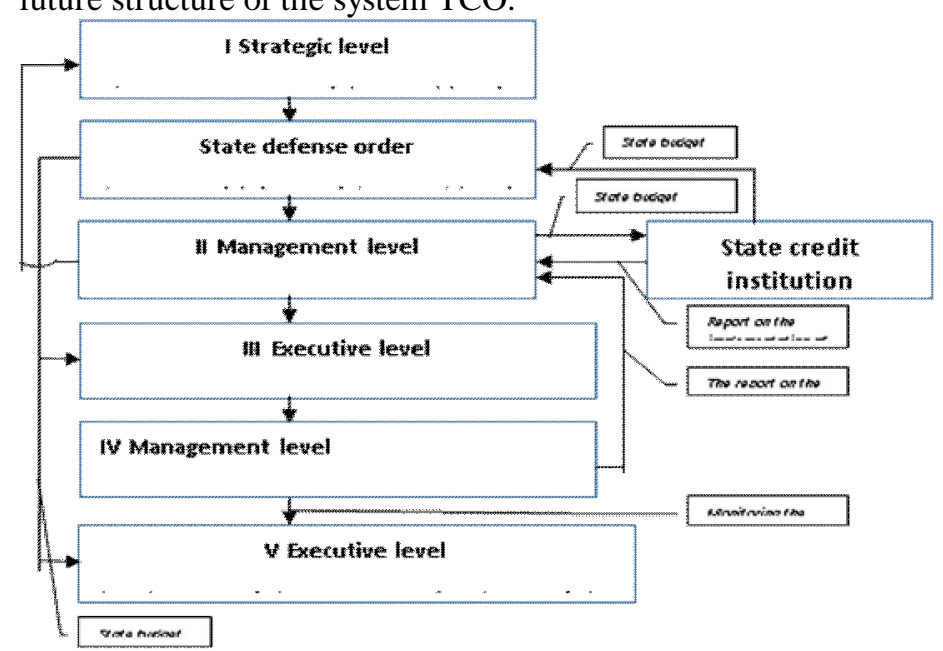

Figure 5: Proposed flow diagram of information flows in the hierarchical management structure of TTCO 
Structural diagram of TCO, which includes consideration of the most difficult organizational-technical system taking into account its hierarchical structure, relationships with the external environment, the establishment of basic principles of management and analyze the process of its functioning.

On the basis of scientific provisions that define the essence of TTCO functioning, the following have been developed: a structural scheme of vertical and horizontal decomposition of the hierarchical structure of the TTK, an improved hierarchical structure of industry management and a scheme for the movement of information flows in it when executing a State order.

\section{ACKNOWLEDGEMENT}

This article is published as part of the research work of program-targeted funding № BR 05236855 "Military-technical and military-technological support of the defense and security of the Republic of Kazakhstan on the basis of economic pragmatism".

\section{REFERENCES}

1. Abramenkov D. E., Abramenkov E. A., Gruzin V. V. Methodology of scientific creativity: Textbook. Karaganda: Bolashak-BASPA, Ed. 2-e. 2007. - 337s.

2. Gruzin A.V., Gruzin V. V. Fundamentals of system research. - Omsk: publishing house of the ANO VPO " Omsk economic Institute, 2008. - $76 \mathrm{p}$.

3. Gruzin V. V. Fundamentals of system analysis. Textbook. - Karaganda: Bola-Shak-BASPA, 2007. - 160 p.

4. Kini R. P., Rife H. Decision-making under many criteria. - Moscow: Radio and communications, 1981. - 484 p.

5. Law of the Republic of Kazakhstan On defense and Armed Forces of the Republic of Kazakhstan (with amendments and additions as of 27.12.2019) https://online.zakon.kz/document/?doc_id=1052592

$-2020-01-13$

6. Pospelov N. N., Gruzin V. V. Development of a structural scheme for improving the military-industrial complex of the Republic of Kazakhstan in the form of a balanced synergetic system. Collection of materials of the International scientific and theoretical conference " new generation Wars and their impact on the development of the military organization of the state - Astana: , 2018. Pp. 430-436.

7. Thorsten Bonacker. The militarization of security. A systems theory perspective. Critical military studies. Center for Conflict Studies, University of Marburg, Marburg, Germany. https://doi.org/10.1080/23337486.2018.1505383 (C) 2018 Informa UK Limited, trading as Taylor \& Francis Group

8. Gonzalo F-de-Córdoba, José L. Torres (2016). National security, military spending and the business cycle. National security, military spending and the business cycle, Defence and Peace Economics, 27:4, 549-570, DOI: $10.1080 / 10242694.2014 .891353$ To link to this article: https://doi.org/10.1080/10242694.2014.891353
9. Emil J. Kirchner, Roberto Dominguez (2014). Security governance in a comparative regional perspective. Routledge Informa Ltd Registered in England and Wales Registered Number: 1072954 Registered office: Mortimer House, 37-41 Mortimer Street, London W1T 3JH, UK European Security Publication details, including instructions for authors and subscription information: http://www.tandfonline.com/loi/feus20

10. Marcel De Haas/ Kazakhstan's Security Policy: Steady as She Goes? Journal of Slavic Military Studies, 28:621-645, 2015 Copyright (C) Taylor \& Francis Group, LLC ISSN: 1351-8046 print/1556-3006 online DOI: 10.1080/13518046.2015.1094939

11. Andrei Kortunov, Yuri Kulchik, Andrei Shoumikhin. View from Russia Military Structures in Kazakhstan: Aims, Parameters, and Some Implications for Russia. Comparative Strategy, Vol. 14, pp. 301-309 0149-5933/95 $\$ 10.00+.00$ Printed in the UK. All rights reserved. Copyright (C) 1995 Taylor \& Francis 


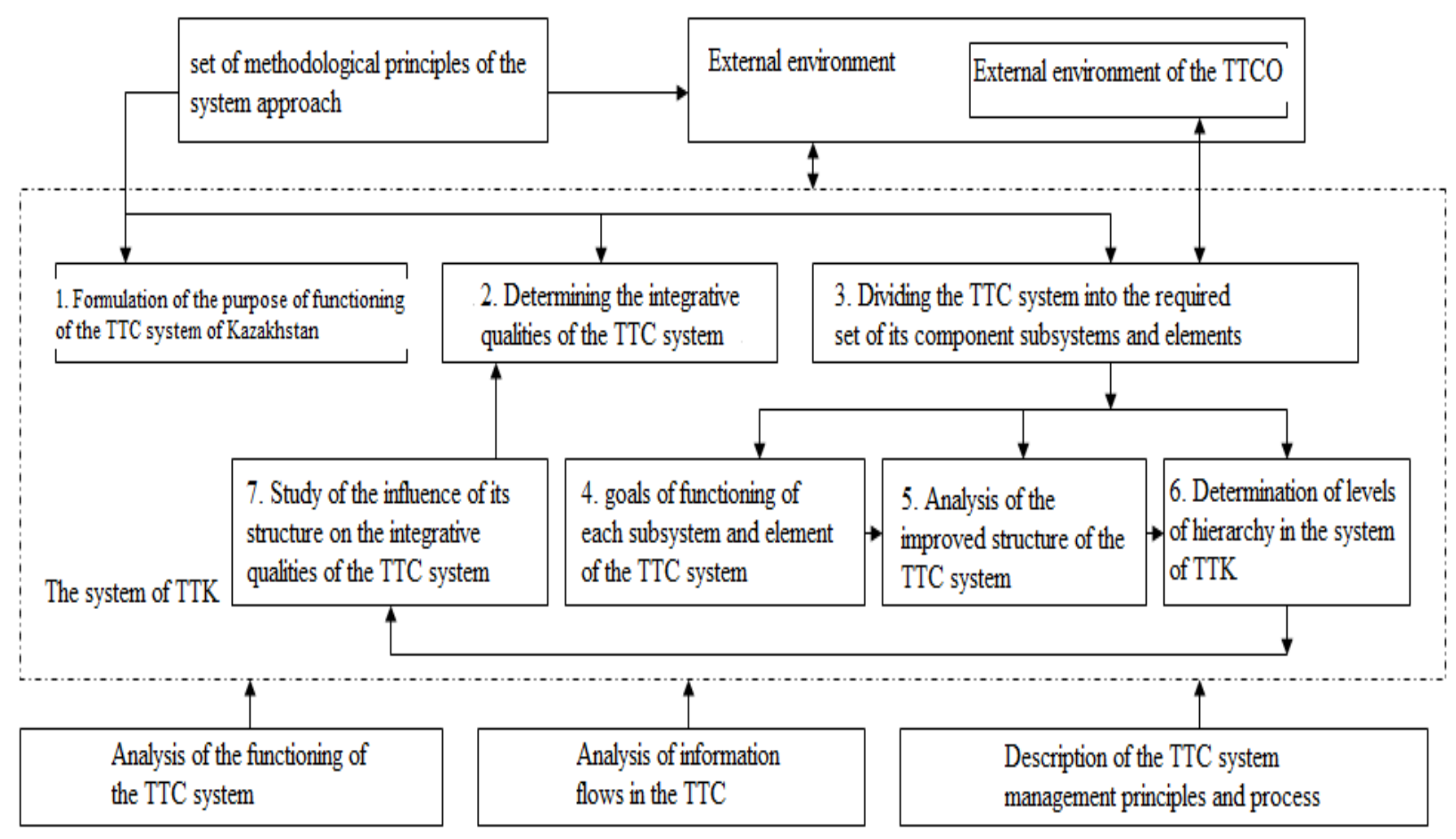

Figure 1: Block diagram of the study of a complex system of technical and technological complex

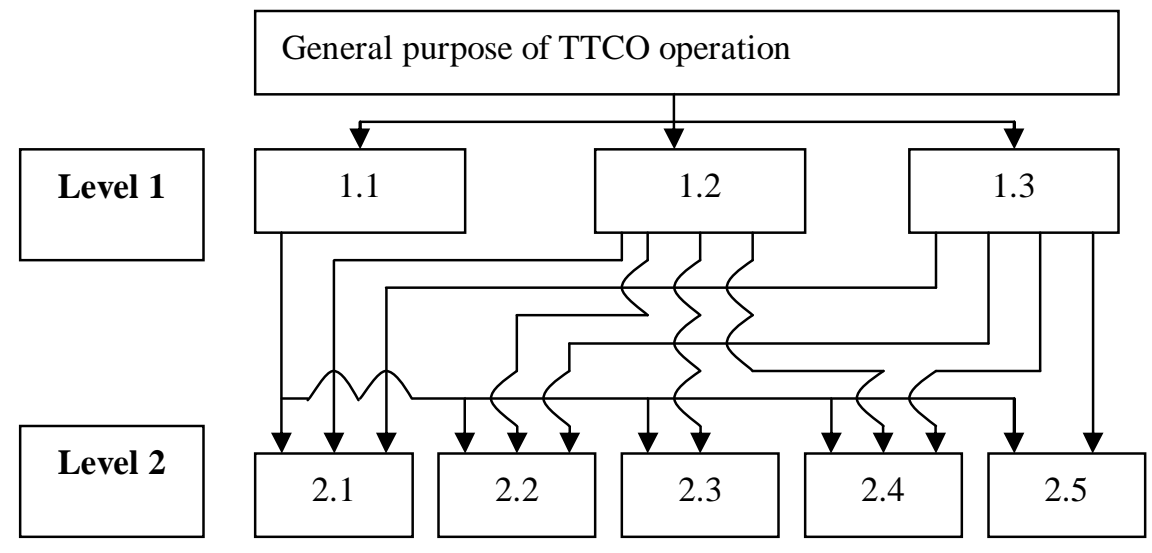

Figure 2 : Structuring the goals of ttco operation 


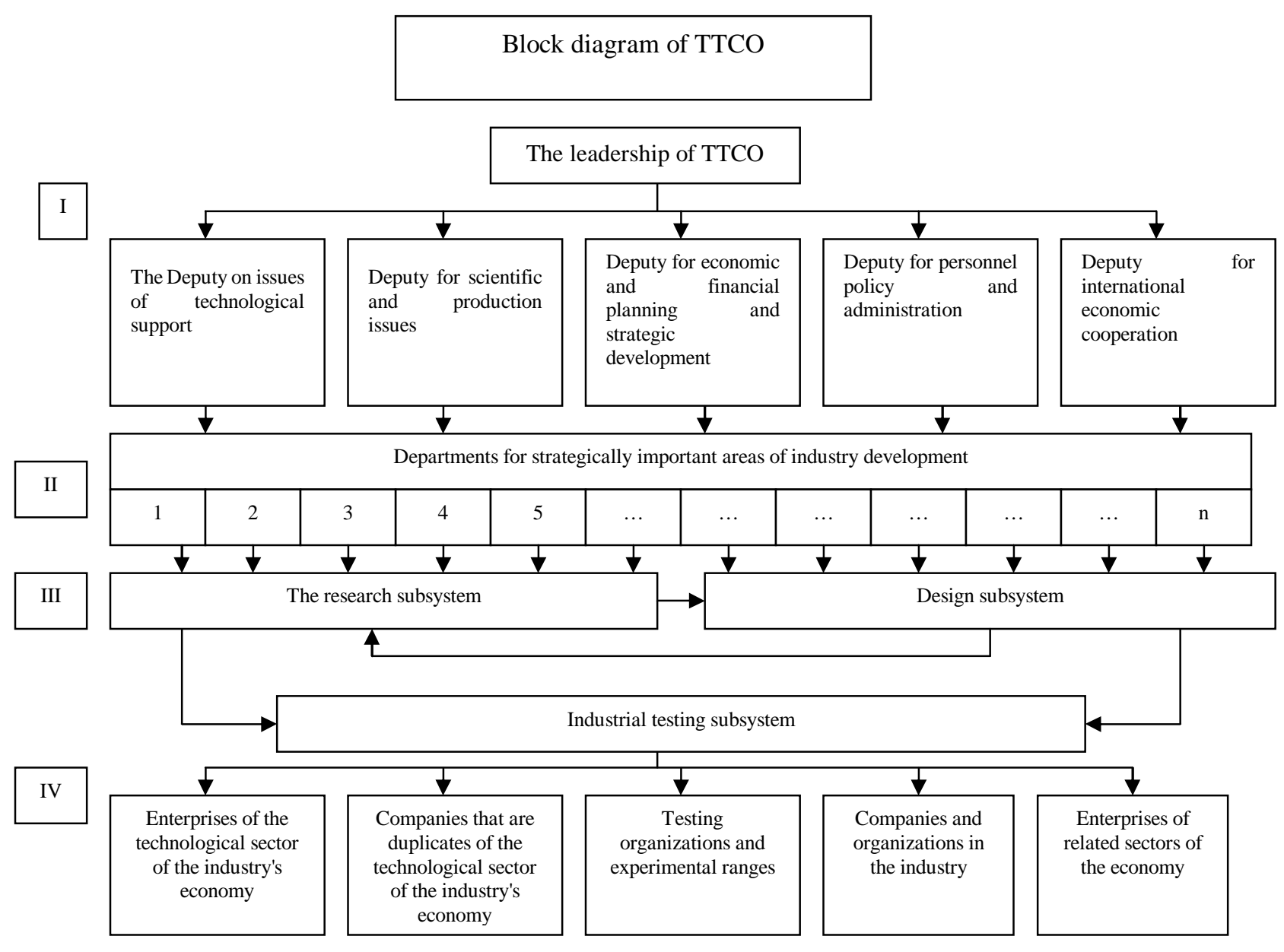

Figure 3: Block diagram of vertical and horizontal decomposition of the hierarchical structure of TTCO 